\title{
Post Mining Area Development; Eco Development Concept Approach
}

\author{
Rustam Hakim Manan ${ }^{1}$, Quintarina Uniaty ${ }^{2}$ \\ Department of Landscape Architecture, Faculty of Landscape Architecture and Environment Technology - Universitas Trisakti - Indonesia \\ Department of Landscape Architecture, aculty of Landscape Architecture and Environment Technology - Universitas Trisakti - Indonesia
}

\begin{abstract}
Eco development gave top priority to considerations in sustainable development. An approachment need to be applied in environmentally prospective on spatial planning, by integrating sub sistem of planning aspects which emphasizes on ecosystem and prediction on its success in order to integrate objectives in economy, social-cultural and environmental. Ex-mining sites in Indonesia need a primary attention due to the environmental damages they caused, by means of reclamation as an effort to restore and increase the quality of its natural resources. Primary consideration in its developing concept is the improving of regional quality with concistency in keeping local potention and characteristic in functional and aesthetic considerations; and give a positive impact for society in ecology, economy, social and cultural. Landscape planning as a developing idea fully responsible to realize the success of exploitation and development of ex-mining sites. Pantai Tanjung Tinggi in Bangka Belitung were choosen as a sample case of post-mining site planning through strategic approachment for a development of beach recreational site, Eco-park; a New Landscape in ex-mining Development based on sustainable local wisdom.
\end{abstract}

Keywords: sustainable development, eco-development, eco-park

\section{Introduction}

The main problems that arise in former mining areas are environmental changes. Chemical changes that occur impact on ground water and surface water, then physically changes the morphology and topography of the land. Furthermore is the micro climate change-induced changes in wind speed, biological habitat disturbances such as flora and fauna, as well as a decrease in soil productivity with the result of being barren. Human activity is the main cause of damage to the environment (ecosystem). Increasing human population, resulting in increased life needs and lead to increased demand for land as agriculture and mining. Development activities often cause damage to the environment, causing environmental degradation, such as damage to ecosystems further threaten and endanger human survival itself. Activities such as forest clearing, mining, agricultural land clearing and settlement, responsible for ecological damage occurs. Consequences include the physical, chemical and biological soil deteriorates; essential nutrient, low $\mathrm{pH}$, contamination by heavy metals in mined land, and a decrease in soil microbial populations. It required an environmental preservation activities in an effort to prevent further damage. Such efforts can be done through rehabilitating ecosystems. By rehabilitation is expected to be able to repair damaged ecosystems so as to recover, close to or even better than the original condition.

Planning should have a regional mining undertake a systematic effort to anticipate environmental protection. Needs to be recognized and agreed that between development and conservation of natural resources should be a balance of the system, which will support the conservation and development guarantee future needs that come up. Need to do a fundamental change in the planning system development through ecology based spatial planning approach to the concept of sustainable development. Reclamation of mined land in addition to an effort to improve the conditions of the post-mining environment, will produce a good ecosystem environment and strived to be better than the first hue, through consideration of the utilization of mineral potential is still there. Reclamation as an alternative effort to prevent erosion or reducing the flow rate of water runoff, and keeping the land in order not labile and can be scaled back its productivity. Reclamation activities aimed at fixing or setting the usefulness land disturbed as a result of mining activities, in order to function and useful designation.

\section{Sustainable Development}

Definition of Sustainable Development by the World Commission on Environment and Development (WCED) in charter Brundtland (1987) is; the develop ment than meets the needs of the present without compromising the ability of future generations to meet Reviews their own needs, namely; development that meets the needs of society at the present time without neglecting the ability of Latter ge coming in to meet their needs. Sustainable development is development that gave birth to the service of environmental, social and economic systems without jeopardizing the existence of the natural, social and built environment as a place to live and depend. Sustainable development aims to improve the quality of human life in all aspects with no waste of non-renewable natural resources and does not exceed the capacity and carrying capacity. Socialisation development should be through the surveillance society where construction supervision mechanism needs to be done vertically-horizontally, so as to constitute a unity of sustainable management, which will result in public confidence and results of development of effective and efficient 


\section{International Journal of Science and Research (IJSR) \\ ISSN (Online): 2319-7064}

Index Copernicus Value (2013): 6.14 | Impact Factor (2015): 6.391

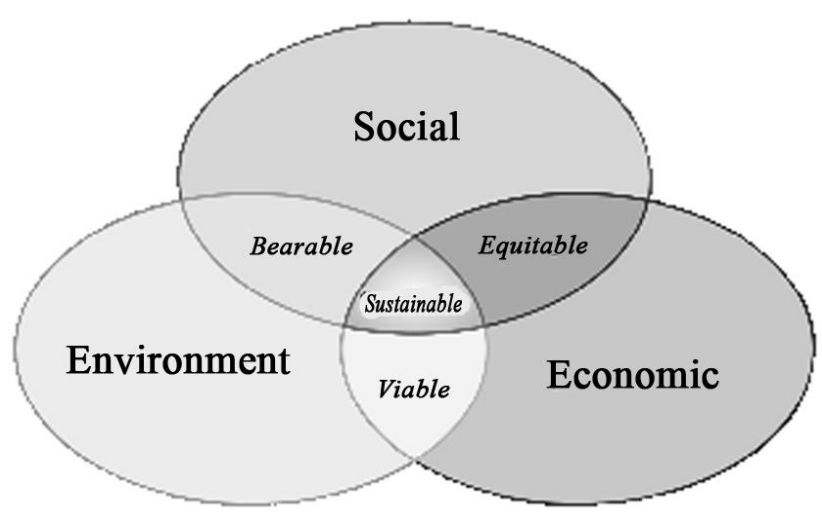

SUSTAINABLE DEVELOPMENT CONCEPT

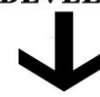

\section{SUSTAINABLE SPACE PLANNING}

BASED ON ECOLOGY

Figure 1: Diagram Concept of Sustainable Development

\section{Approach to the Concept Of Sustainability}

Human activity is the biggest consumer of the use of natural resources. Development of sustainable development is essential to every aspect of human life, as well as for postmining land. On the concept of sustainability is expected to human activities can always take advantage of natural resources at the same time rescue efforts for the next generation.

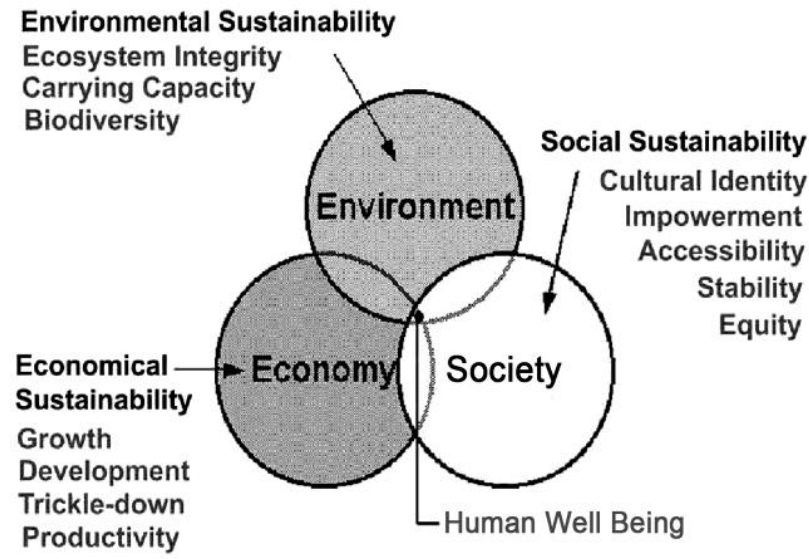

Figure 2: Diagram of the Quality of Life Improved Relations With Sustainable Development Source; Jenks, M. Burton, E, William, K, 1996

\section{Eco Sustainable Development in the Landscape}

Ecodevelopment development in the application of ecologybased regional planning is a wise solution strategy; a network planner's strategy and management of the ecological sustainability of the process; landscaping and green open spaces that will protect the values and functions of natural ecosystems and to increase the benefits for human life. As part of the concept of sustainable development; development of eco development will affect the sustainability of environmental systems, social and economic aspects. As the parameters of support and development to support the successful planning and
Sustainable development is based on two related concepts, namely; (1) The concept of necessity (the concept of needs); create conditions that keep the remains unmet needs masya living adequate for the society; (2) The concept of limitations (the concept of limits); pay attention and maintain the capacity of the environment to meet the needs of the present and the future.

In the discourse of the environment, 'sustainable' is often used as a generic term to refer to the term 'ecologically sustainable' or 'environmentally sustainable'. In the midtwentieth century, humans began to understand fully that the continuity of human existence relies on network natural processes. The capacity of these systems to support a limited life and are very likely to be reduced by the existing demands. Human activity can be considered 'ecologically sustainable', if the activity does not diminish the capacity of natural systems to support life. Activity is considered to be 'ecologically unsustainable', if he can not continue in the long term without membaha yakan systems that allow for life. The term 'carrying capacity' has been used in ecology to refer to the maximum number of species that can be supported by a region within a specified period.

Sustainability accommodate the principles of sustainable development that prioritizes the integration of development on the natural environment, sustainable economic and social understanding can be shown as Figure 2 below:

sustainable development as support for the concept of Sustainable Landscape by the method; calculate, plan, and design the landscape based on the calculation of the energy balance and energy cycle in an environment or ecosystem. Redevelopment of green areas in the form of forests, both in urban and rural areas mined land and protected areas are thought wise, planning and development functions of the green needs to be fully supported in the policy of national politics, so that its benefits can be built systemically and constantly. The capacity of a landscape can be measured to carry out productive activities and planned landscaping to maximize efficiency and productivity. Because the future landscape will not be assessed through political value, or display financial values, but their potential ecological sustainability are integral to the flow of energy at each site, the area, the ecosystem or biome. Finally, the challenge is to find a balance between human and natural ecosystems, and to find ways to sustain the environment and landscape using natural ecological efficiency. In the form of implementation at the regional planning approach is through the Eco Development.

Eco Development requires the construction of infrastructure Green in the form of strategic planning and distribution system network of green spaces are of high quality and characteristics of other natural, designed and managed as an ability multipurpose resource with the ability to repair and give the man faat ecological quality of life; community; needed to support the sustainability (sustainability) system environment (Benedict, Mark, A., and Edward, T. Mc.Mohan. 2001). Planning and management should be able to improve the characteristics and peculiarities of a region/ area manner that reflects the existing habitats and types of landscape, including establishing green spaces and tread 


\section{International Journal of Science and Research (IJSR) \\ ISSN (Online): 2319-7064 \\ Index Copernicus Value (2013): 6.14 | Impact Factor (2015): 6.391}

with new functions in the built environment and regions of the main activities to the area of the buffer, Thereby necessary spread to the rest of the spatial scale of the subregional level to the level of the environment as a network, so it can accommodate the entire natural green spaces into the local community and the region and the wider area

The approach needs to be applied in landscape planning and design are as follows:

- Assessing / assessment: an assessment of the quality of the environment in relation to the carrying capacity of the region,

- Planning / planning; regional planning based environment with emphasis on pitch as ecology,

- Designing / design; where the design of the area is a subsystem of planning in a broader scale.

Development of Eco-park system planning area well within the scope of regional, district or to the region or the soles is limited to positive alternatives. In this case intended for regional and post-mining land. These efforts will realize increased land preservation and conservation of the water system. Eco-effectiveness and Eco-efficiently Against Ecological and Economic Aspects In Eco Development Concept

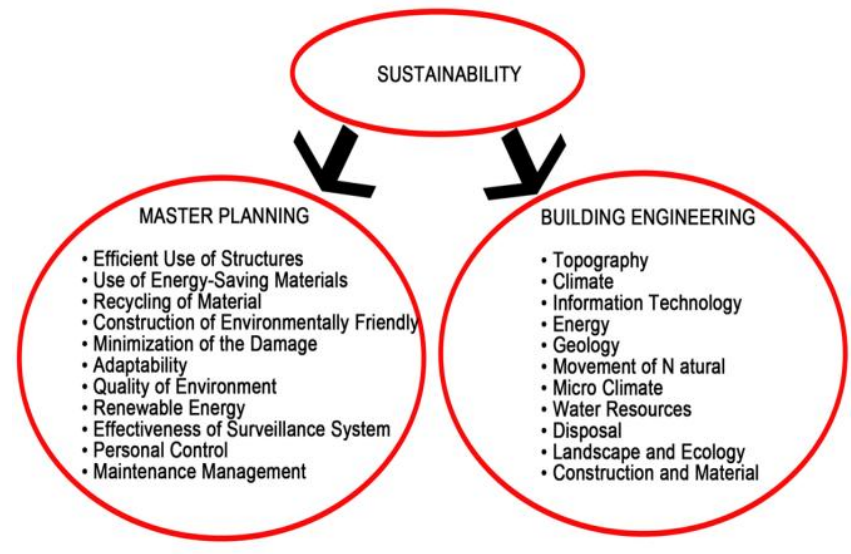

Its application to the design of the area beckon us to better do pertimbnagan environmental considerations, involving ecological, economic and cultural development which will bear eco as a more responsible approach.

\section{Bangka Belitung Eco Park New Landscape in Ex-Mining Development}

Planning area is located at the location between the city and Sungailiat Pangkalpinang which is largely a post-mining area covering +/- 1100 ha. Long area of nearly $5 \mathrm{~km}$ of provincial road linking Pangkalpinang in the south and Sungailiat next to its North. Goals and Objectives regional development is to produce a design that can improve the environmental quality of the post-mining tin, developing the potential of nature be based on the principles of ecological tourism area, integrating community activities in ecotourism.

\section{Soil Conditions and Topography}

Topography in the area of ex mining river clay soil is bercerun. Uneven tread surface, is a result of the mine excavation conducted unplanned. But in terms of landscape, this condition is very favorable because forming spaces that occur from the barrow excavation of the mine.

Landscape space occurs due to deposition of excavated mine, the potential to produce an attractive visual landscape. Natural potentially utilized as a source of fisheries and recreation, but perluklarifikasi pond water pollution. ondisi ground surface is damaged and requires handling of the physical form of the soil surface soil surface forming ondisi memorable landscape or peat bogs. Is the potential for a very interesting visual landscape. Mining process, making the former mine land has the appearance and physical properties and fertility of the same is very bad. Overlays tailings deposition material is composed of quartz sand to pebblesized layered, the farther the distance from the Jig finer material mixed with a little clay. This material has the potential fertility of extreme low with the properties bind water and cations are also very small, organic matter content, P-available, CEC, the levels of alkaline (Ca, Mg, K, $\mathrm{Na}$ ) extreme low with a $\mathrm{pH}$ between 5.0 - 6.0 and generally textured sand and argillaceous sand, giving the impression of the atmosphere of the desert bald except in the parts that have not disturbed and quite humid, there are certain vegetation development. Waterless pit area, the situation is relatively the same. Under - under the open on the grounds Kong (Consolidated) or under-buried under tailings material and stripping, generally no plants are growing.

\section{Public Social Conditions}

(Source: Kaka Enindita Initiatives, 2008, Report of the Job Training Monitoring of Land Reclamation Mine Closure In PT.Timah (Persero) Tbk, Department of Silviculture, Faculty of Forestry, Bogor Agricultural University). Conditions in Bangka Island communities are very diverse and heterogeneous, style of living, can be distinguished from the type of their livelihood. there are various tribes and religions and beliefs. Inhabited island of Bangka besides native island itself is Javanese, Acehnese, Batak, Palembang, Padang, Bugis, Madurese, Chinese, Ambon, and others. Ethnic diversity in Bangka Island making diverse livelihood patterns they run, most of them work as farmers, laborers / employees of the mines, traders and fishermen. The presence of lead in Bangka Island, as well as the amount of tin mining in Bangka Island both on land and offshore causing not only the people of the city who perform mining activities are but a majority of the population on the island of Bangka both located in the city, the countryside, and coastal communities and the migrants work as miners, and on the sidelines of their job of planting and trade outside working hours. The state of native land in Bangka Island is suitable for plantations such as oil palm and rubber, it makes the rise of rubber plantations, pepper, coconut, and palm oil. Some land reclamation also be used as oil palm plantations to increase the value of post-mining land. The plantation products are sold outside the region or abroad, which is the source of income for farmers so as to encourage them to increase their efforts in this field. Bangka Island has a very rich waters of both tin and fish catches. This situation 


\section{International Journal of Science and Research (IJSR) \\ ISSN (Online): 2319-7064 \\ Index Copernicus Value (2013): 6.14 | Impact Factor (2015): 6.391}

attracted the attention of fishermen from other places like Bugis tribe, which initially only come once in a while and in the end many of them are settled and made a settlement there. Fish catches in Bangka sold well out of the area and as an export, besides a byproduct of fishing activities is the root bahar which is then sold to the craftsmen root bahar to be souvenirs that are well known at home and abroad, the center craftsmen root bahar located in the western region of Bangka Muntok. Because it is not an area with good pasture it to the needs of society Bangka meat at first cattle brought from outside the area, among others, Madura, Bali and Sumbawa. This raises the appeal for people to do business and raise cattle on Bangka Island in addition to planting crops, especially corn. Trading business is generally conducted by Bangka Chinese society, not only in the city but to the villages, except that in some of their coastal fishermen, they also cultivate vegetables and raise pigs.

\section{Landscape Vegetation Conditions}

Based on visual observations at the site of the design, some types of plants can live well and thrive in fertile. These crops is a capital landscape which should be utilized as part of ornament softscape.in landscape design

\section{Climate}

Bangka Belitung Islands has a tropical climate that is influenced by monsoons that experienced a wet month for seven months throughout the year and month of the dry dive five months continuously. 2005 dry season occurs from May to September with rainy days $11-15$ days per month. For wet month of rainy days 15-27 days per month, occurred in October to July and March and December.

\section{Visual Landscape}

Visual landscape encountered in field observation, namely (1) The shape of the land surface has been damaged forming pile hilly land. The hilly land is a potential landscape to form outer spaces become more varied.; (2) Various types of wild plants can be utilized to provide a more natural impression; (3)The beach with white sand and a collection of large stones is the appeal of the waterfront.

\section{Forms and Spatial Design Concept}

\section{Zones Research and Education}

This zone is located on post-mining land in which already conducted a trial planting of various types of local plants). This zone is directed as an area that facilitates research activities and education are supported by facilities and infrastructure in accordance with the type of activities, such as: network infrastructure, laboratories, educational buildings and others, which aims to determine the quality of soil, water and air post-mining land and the possibility of utilization and development. In the reserved zone mining museum facilities; museum which shows the mining process through various audio-visual media in a closed room. The museum is also equipped with an open museum that allows visitors could conduct mining process directly with the supervision of the manager of the museum. The entire physical facilities in this zone is only allowed to use $15 \%$ of the total land area. Other land area should be revegetated with perennials using local Bangka Belitung. In this zone there is one entrance to the area from the western side of the road. This road is an existing provincial roads that connect cities and towns Sungailiat Lists Pinang. Designation in this zone emphasis on experimentation and pilot zones for the development and utilization of reclaimed area of traces of mining in Sumatra in general and the Pacific Islands at coal mines in particular. can also be used as a place of research, a natural laboratory, which is useful for the improvement of soil structure, nutrients and water to the land-mined land other Pacific Islands, The approach in the implementation of laboratory experiments and the land by focusing the Ecotechnology renewable (sustainable) so that the utilization of a zone will have a positive impact and be useful zone. Especially for the laboratory area is separate and aloof as standard the existence of the laboratory. Overall this zone is expected to be tested for routine needs with "smart house", where demand for electricity, water, cooking, vegetables, milk and other self-supply used technology more advanced. Like electricity using wind power and solar power. Diesel fuel by using environmentally friendly technologies from the developed world countries. Water using a special filter so that the water you drink is water distilled from the region. Fuels from bio-diesel produced from (seeds nyamplung) and others. Such as vegetables with hydroponik, fertilizer used from other pet droppings in addition to the use of microorganisms and earthworms can fertilize the land. In this zone also made mine museum (indoor and outdoor) is an indoor museum is a museum like in general. While the outdoor museum that displays how mining until the results where visitors can see first hand what the mining process. the exact location. Selection of the material in its application: Neo Landscape one solution with two objectives, namely functional and aesthetic. Broadly speaking, must have a local character, ecoteknologi and beneficial to the region in particular and for the region / other zones in the Pacific Belitung pada general. Such as the use of rocks around it that can be used (ground corn), bricks are made and printed with good combustion technique so powerful for both indoor and outdoor.

Highway so using local materials such as ground corn, pieces of granite in addition to the concrete in order to facilitate the maintenance (see picture detail). Street furniture is expected to use natural resources such as timber are no rocks and so on, so that the local impression gained very good shape, material and color. (Exploration of the wealth / local wisdom to be a better condition. 


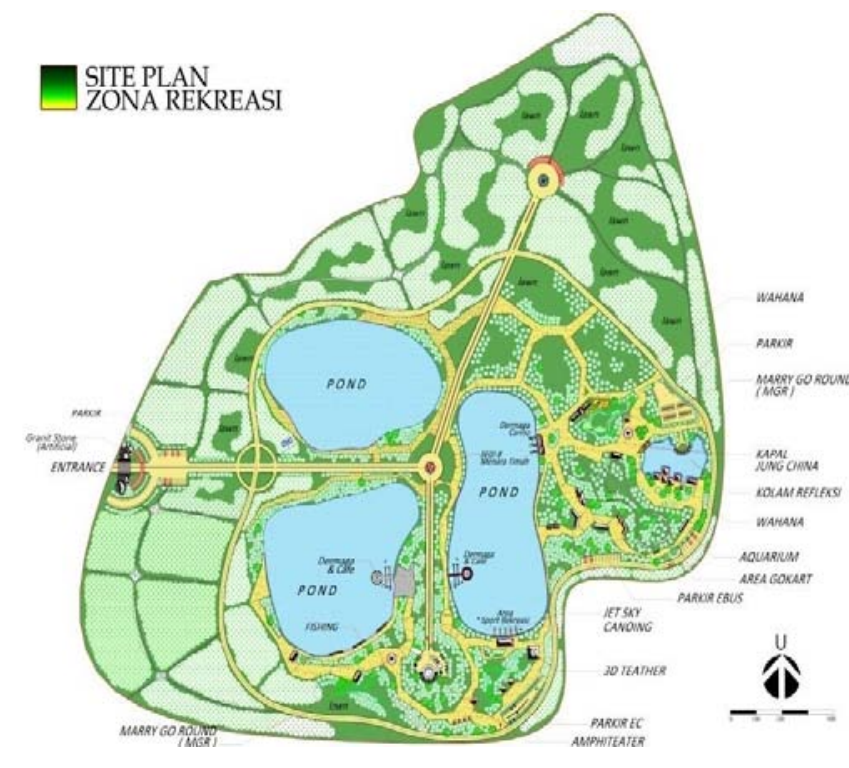

\section{Recreation Zone}

This zone is selected in a region that has little managed to grow some types of aquatic plants such as: Ropes, Purun, Acacia, Waru sea, Ketapang and Oil Palm and other crops so that for subsequent success need to approach other ecological well-tested as a driver / booster to get two goals of green recreational and environmental improvements as well.

\section{Eco Resort Zone}

Zone eco resort, expected a formation region more successful when compared to the other two locations due to natural conditions more favorable to the $\mathrm{PH}$ soil and conditions of sea sand that almost every time the tides is good enough to create better conditions and among others by preparing types -type plants will be planted (sown around locations) corresponding to coastal habitats, or other coastal plants. It is apparent from the existing plant virtually all coastal plants can be successfully grown well.

\section{Conclusion}

The built environment and natural resources earmarked for humans. Preserving the environment and the constraints and rules of the rule is very important for the survival of a society. There is a need for tools and design processes that enable people to participate in decision-making, to understand the design issues involved, and to describe creatively and observe the application of different options. Development planning mining area based ecology requires an understanding that an area is affected and affect the ecological system of the wider region which is embodied in the design of the physical structure planned and woke up on the land and planning of natural resources under the land up horizontally and vertically in order to realize the goal of an ideal a sustainable planning and design. And it is also necessary through the management and oversight mechanisms in growth and development. Implementation of development should be done in an integrated manner by all development actors (stakeholders); government-among experts-educational institution-wide community. Socialization should regional development through community supervision, where construction supervision mechanism needs to be done vertically-horizontally, so as to constitute a single entity, sustainable management, which will result in public confidence and results of regional development of effective and efficient.

\section{References}

[1] Aqa, Sayed (Ed). (2008), Consolidated Research Sustainable Urban Development, United Nations Development Programme Sub-Regional Resource Facility - Arab States, Developed by SURF-AS KST.

[2] Aydin, Osdemir. (2007). Urban Sustainability and Open Spaces Networks, Journal of Applied Sciences 7 (23), 3713-3720.

[3] Battle Guy and Christopher Mc. Carthy, 2001, Sustainable Eco systems and the Built Envi ronment, Wiley Academy,John Wiley and Sons Ltd., New York.

[4] Benson, John. F, and Maggie H Roe, 2000, Landscape and Sustaina bility, Spon Press, London.

[5] Chapman, David, 1996, Creating Neighbourhoods and Places in the Built Environment, E \& FN Spon, London.

[6] Cohen, Nahoum, 1999, Urban Conser vation, the MIT Press, Cam bridge.

[7] Foo, A.F, Belinda Yuen, 1999, Sustai nable Cities in the $21^{\text {st }}$ Century, Faculty of Architecture, Building\&Real Estate, National University of Singapore, Singa pore University Press.

[8] Gilbert, O. L. (1989). The Ecology of Urban Habitat. London: Chapman and Hall.

[9] Jack Todd, Nancy and John Todd, 1994, From EcoCities to Living Machines, Principles of Ecological Design, North At lantic Book, Berkeley, Califor nia.

[10] Katz, Peter, 1994, The New Urbanism Toward an Architecture Community, McGraw-Hill Inc, New York.

[11] Li and Wang. (2003). Evaluation, planning and prediction of ecosystem services of urban green space: a case study of Yangzhou City. Journal Acta Ecol. Sin. 23(9), 1929-1936

[12] Page, Robert. R, Cathy A. Gilbert, Susan A. Dolan , 1998. A Guide To Cultural Landscape Reports; Contents, Process and Techniques, U.S. Depart ment of Interior National Park Service, Cultural Resource Ste wardship and Partnerships; Park Historic Structures and Cultural Landscapes Program, Washington, DC

[13] Srinivas, Hari, 1997, Information System in Urban Environ mental Management, Interna tional Seminar, Groningen. 